\title{
Exploration of the Lattice Shop Environment in the Post- epidemic Era
}

\author{
Penghao Wang ${ }^{1, *}$, Haoning Zhang ${ }^{2}$, Xingxing Liu ${ }^{1}$, Xun Jiang ${ }^{1}$, and Xiaoshan Ding ${ }^{1}$ \\ ${ }^{1}$ Qingdao University of Technology, School Of Management Engineering, 266000 Qingdao, China \\ ${ }^{2}$ Qingdao University of Technology, School Of Information and Control Engineering, 266000 Qingdao, China
}

\begin{abstract}
In the post epidemic era, mass entrepreneurship and innovation have become an important driving force to promote the domestic economic cycle and the domestic and international double cycle. Lattice shop has the characteristics of novelty, convenience and low threshold, which can better adapt to the new retail formats, and then build an entrepreneurial service platform. Through the analysis of macroeconomic background, taking Qingdao as an example, this paper investigates the market environment through marketing channels, market characteristics and economic scale, sums up the main factors for the construction of lattice shop location, and provides practical suggestions for the construction of lattice shop platform in this region, so as to promote the industrial innovation and development of lattice shop business model in the local market.
\end{abstract}

\section{Research background}

\subsection{Research purpose and significance}

In order to study the impact of China's market economy in the late stage of epidemic control from the beginning of 2020 to the present, small and micro enterprises represented by the lattice shop are still in the embryonic stage under the influence of the epidemic, but in the rapidly changing new environment, how can small and micro enterprises such as the lattice shop steadily complete the shop location, landing, management and management. According to the market data and national policies, this paper will analyse the market changes of lattice shop in the post epidemic era and the problems exposed under such market changes, and discuss the construction direction and development strategy of lattice shop [1-2].

\subsection{Time and policy background}

In 2020, COVID-19 has swept all over the world, bringing great impact on the global economy and society, with far-reaching impact. New York Times columnist Friedman proposed BC (before Coronavirus) and AC (after Coronavirus), which divided the epidemic into two periods.

At the meeting of the Political Bureau of the CPC Central Committee in 2020, the CPC Central Committee has already stressed: "the current economic situation is still complex and severe, unstable and uncertain. Many of the problems we encounter are medium and long-term. We must understand them from the perspective of protracted war, and speed up the new development pattern with the domestic big cycle as the main body and the domestic and international double cycles promoting each other." For China's economic development model, the dual cycle pattern with internal circulation as the core means that the focus of economic development is internal revenue. In the next few years, economic growth will be more dependent on the domestic market, and the market environment will also enter the stock stage from the past incremental stage. Under the external environment of epidemic situation and uncertainty, the combination of rational consumption concept and new demand under consumption upgrading will obviously usher in a prosperity of domestic second-hand commodity market [3-5].

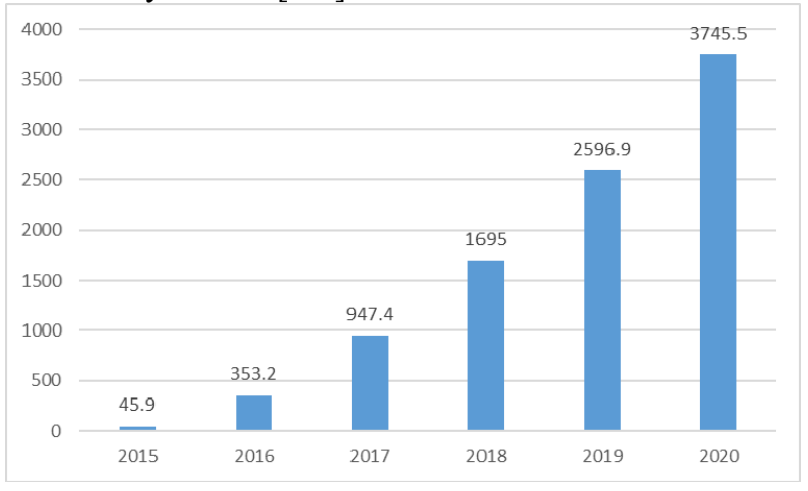

Fig 1. Data chart of the scale of second hand e-commerce industry (100 million yuan)

According to the survey, the scale of China's secondhand e-commerce market will reach 259.69 billion yuan in 2019 , with a year-on-year increase of $53.2 \%$. It is estimated that the scale of second-hand e-commerce will reach 374.55 billion yuan in 2020 (see Figure 1). The

\footnotetext{
* Corresponding author: 2772738271@qq.com
} 
scale of second-hand e-commerce reflects the potential huge market and the overall upward industry situation. However, on the other hand, the high cost for users to obtain and the poor logistics service and after-sales service also restrict the development of e-commerce, and the market demand for physical stores is becoming stronger and stronger. But for most people, the high rent and management costs of opening physical stores are really hard to afford. The emergence of lattice shop is to solve this pain point.

It is not only a second-hand commodity, but also a convenient platform for entrepreneurs. By reducing rent and renting lattice, it provides entrepreneurs with a cheap commodity display platform, which not only helps entrepreneurs realize their entrepreneurial dream, but also realizes their economic benefits.

In fact, Premier Keqiang Li stressed at this year's executive meeting of the State Council that it is necessary to further promote mass entrepreneurship and innovation, focus on supporting the employment and Entrepreneurship of college graduates and other groups, make good use of special bonds of local governments, strengthen the connection between funds and projects, and pass the regulations on the implementation of the budget law of the people's Republic of China (Revised Draft). This is undoubtedly a huge policy welfare for many college graduates and entrepreneurs with certain ability, and the lattice shop, as an upstream platform, can undoubtedly play a greater role in it.

To sum up, the world economic situation after the epidemic is grim and complex, on the other hand, it promotes the prosperity of the second-hand commodity market. China has launched a policy to encourage the public to start businesses, and the funds will be tilted to entrepreneurs. The lattice shop, which has the functions of entrepreneurial commodity display and second-hand trading platform, has a good development trend.

\subsection{The definition of Lattice shop}

Lattice shop originated from a large shopping mall in Tokyo, Japan. Its founder is a Japanese businessman. The concept of lattice shop was introduced into Hong Kong in the winter of 2005. In a short period of about one year, many shopping malls in Hong Kong have developed to the scale of more than 100 shops. The business model of renting lattice shops to sell goods has developed successfully in Hong Kong. Many lattice shops have formed a scale and opened chain stores.

Nowadays, the lattice style has begun to sweep the mainland, and many lattice shops have appeared in Beijing, Shanghai, Guangzhou, Shenzhen and other major cities. In addition to the lattice shop form, many entrepreneurs have become professional lattice owners. They have their own lattice cabinets in many lattice shops, and some even create their own brands. In the face of the surging trend of lattice, people gradually believe that lattice shop is not only a temporary trend, but also has more development space in the future.

For the audience, it is a new shopping mode popular among young people in recent years, especially among white-collar workers. Lattice shop is generally opened in the fashion area of leisure shopping. Compared with the traditional shopping malls, the design of lattice shop is exquisite and unique, and the goods are unique, so it is favoured by white-collar workers. Many people are tired of this stereotyped shopping mode because all kinds of goods in traditional stores are basically the same. Similar brands and similar clothes can be bought everywhere. As a new form of sales and exhibition, plaid shop has a rich variety of handicrafts and exhibits, which deeply attracts a large number of consumers.

The post epidemic era is different from the past, many businesses are not in order to start a business to settle in the lattice shop, but in the form of "forced". Many workers who are out of business at home begin to follow the call and implement the stall economy. However, the construction of urban environment and the risk that the virus has not completely disappeared still exist. During this period, lattice shops seize the opportunity to carry out innovation, standardize the stall economy, and make the stall enter the lattice, so as to not only ensure the demand of businesses, but also make the products of lattice shops more novel and diverse, At the same time, the lattice shop can also respond to the call of governments at all levels to sell agricultural products, promote agricultural products on the online platform, and help reduce the pressure of accumulation of agricultural products.

\section{Analysis on market environment of lattice shop}

\subsection{Existing market environment of lattice shop}

With the popularity of the Internet and the wide use of related electronic devices, more and more students choose the Internet as an attempt to start a business. On the one hand, the reason is that the cost of starting a business online is relatively low and the pressure of starting a business is relatively small. On the other hand, the popularization of online sales channels greatly facilitates the acquisition of resources and customers, and more efficiently selects suitable resources and customers, which reduces the cost of procurement and marketing to a certain extent, It also reduces the difficulty of entrepreneurship to a certain extent.

Marketing channel is very important for products to enter the market smoothly and maintain a high market share. In the post epidemic period, in order to prevent the virus from coming back and ensure the health of students, most colleges and universities did not open the instruction of free access to the school, so that the lattice shop can enter the campus and connect online and offline, which provides convenience for the "home life" under the epidemic situation. The closed door of university brings the tutoring career of many students to an end. However, although many college students do not have much social experience, they also need enthusiasm and economic independence. The combination of lattice shop and Internet also provides a practical channel for this idea. Therefore, the entry of lattice shop makes 
many students contact the outside world to carry out goods circulation through the establishment of lattice shop. And this phenomenon is undoubtedly a great opportunity for the lattice shop. The market demand of a large area makes the profit more, and the development of lattice shop is also considerable.

In contrast, the traditional off-line entrepreneurship and industry have few choices for students, because they have the same entrepreneurial model and strong competition with the network. The small scale of entrepreneurship often brings great economic burden to entrepreneurs. Most of them are small start-ups with a few people, which are easy to fail, but also have development potential. 58 official housing search platforms in the same city show that, taking Qingdao as an example, the rent pricing of shops shows great differences under the influence of location, area and other aspects, but the overall price is relatively high, which is a heavy burden for college students and small and micro businesses. In this market environment, private lattice emerges as the times require.

\subsection{Market information feedback}

At present, the flexibility and low cost of lattice shop cater to the employment development situation of mass entrepreneurship and innovation. Today, with the development of diversified technical means and new management mode, lattice shop provides a high-quality and reliable practice platform for partners and new concept marketing management mode. As of November 25, 2016, there were 11371 registered stores, 177119 registered lattices and 5689435 registered commodities. There are about 7400 stores in the East and 3600 stores in the West. Among them, the most popular form is campus lattice shop, which mainly deals with secondhand products and consignment. Tenants only need to pay a relatively low rent every month to sell their goods in the lattice shop. Taking the campus lattice shop as an example, the lattice shop distributed around the campus. According to the information collected from the network and field visits, the campus lattice shop is mainly concentrated in the first and second tier cities, but there are scattered distribution around the universities in some municipal cities. From the overall distribution, the campus lattice shop in the eastern region is more than that in the western region.

To sum up, the world economic situation after the epidemic is grim and complex, on the other hand, it promotes the prosperity of the second-hand commodity market. China has launched a policy to encourage the public to start businesses, and the funds will be tilted to entrepreneurs. The lattice shop, which has the functions of entrepreneurial commodity display and second-hand trading platform, has a good development trend.

\subsection{Existing problems}

\subsubsection{Single business market}

Due to the size limitation of the traditional lattice shop, it usually only sells some scattered goods and idle secondhand goods. The source of goods is relatively single, which easily makes the lattice shop assimilated by the traditional jewellery shop, and lacks its own characteristics, leading to the decrease of competitiveness.

\subsubsection{Restrictions on customer groups}

The traditional lattice shop only sells by offline way, the customer group can only radiate the surrounding residents, and the single source of goods also limits the scope of the customer group, and cannot achieve the maximum coverage.

\subsubsection{Single propaganda mode}

The traditional lattice shop only takes the poster as its propaganda mode, and the audience group is less, and the poster needs to obtain the authorization of response, and can not be randomly posted in the major streets, so the propaganda is small and the scope of propaganda is narrow.

Lattice shop new business model, attracting many young people to join them. However, the current situation is due to many tenants, difficult management, single mode and other problems, half of the popular lattice shops have closed down. In the relevant investigation and interview, it can be found from the operation status of some lattice shops that the business is cold and the salesperson's attitude is very cold. In the areas where many lattice shops were opened, some shops have advertised for transfer, and more than half of them have closed down. After renting and selling the lattice, the owners of the lattice sell different styles of goods, so it is difficult to package them as a whole to create characteristics. If the tenant's things have no characteristics, it will lead to poor sales. After losing money for a few months, the tenant will give up the renewal. It can create a vicious circle.

Based on such opportunities and challenges, private lattice has constantly improved its business model, learned from the experience of all parties, formed a unique business philosophy and built it.

\section{Suggestions and strategies}

Globally, the epidemic is still ongoing. According to the requirements of the national leaders on the policy situation of "strengthening domestic circulation and double circulation at home and abroad" of China's economy, according to the above theories, methods and data, combined with the analysis of the current market situation and the development of China's market economy in the post epidemic era, this paper puts 
forward some suggestions for the market research stage of lattice shop.

\subsection{Research on location of target market area}

In order to obtain better business volume and ensure the long-term profit and development of lattice shop in the future, before confirming the target market, when collecting more detailed data of target customers, regional market environment investigation and analysis should be conducted for each initial target area in the city. When analysing the market environment of a certain region, due to the particularity of the types and forms of lattice shop sales, the selection of evaluation elements and projects should not only focus on the flow of people and profit rate, but also include the elements with regional cooperation and development potential. For example, the business district, the survey of consumption capacity, the proportion of people flow in different periods, and the later development, including the benefits and impacts of urban infrastructure construction on the future economic environment and passenger flow of the region.

In the past, the business circle effect often had a great influence on the decision-making of the market positioning of the physical lattice shop, but at the same time, the economic income of the residents or office workers in an area often restricted the turnover of the lattice shop, which is also the reason for considering the business circle effect and the economic ability of the market consumers and target customers. In the investigation of the surrounding market environment, we should pay attention to the existing market types, and pay attention to the level, scale and investment suitability between lattice shops and similar types of shops. As long as you are in the market, the competitive relationship will appear sooner or later. When you are in the market environment with multiple competitive relationships, you should timely adjust the market positioning, including target customer group, physical store planning, marketing strategy, and innovative online publicity mode.

The selected market should have rapid penetration, that is, to spread in as wide a region as possible in unit time. Due to the high cost of opening lattice shop, various types of products and fast update speed, in order to quickly occupy the market and achieve greater economic benefits in a short time, we must maintain the consumption level and population of the surrounding consumer groups. Taking the private buildings in Laoshan District of Qingdao City as an example, according to the GDP data uniformly calculated by the Statistics Department of Qingdao City in the first quarter of 2020, this paper sorts out the per capita GDP data, year-on-year growth data and ranking of the districts (cities) under the jurisdiction of the city in the first quarter of 2020. The detailed data are shown in Table 1.

Table 1. Ranking table of per capita GDP / year-on-year growth rate of Qingdao City, Shandong Province in the first quarter of 2020

\begin{tabular}{|c|c|c|c|c|c|c|}
\hline $\begin{array}{l}\text { Per capita } \\
\text { ranking }\end{array}$ & District (city) & $\begin{array}{l}\text { GDP in the first } \\
\text { quarter of } 2020 \\
\text { (100 million } \\
\text { yuan) }\end{array}$ & $\begin{array}{c}\text { Permanent } \\
\text { population by } \\
\text { the end of } 2019 \\
(10000) \\
\end{array}$ & $\begin{array}{l}\text { GDP per capita in } \\
\text { the first quarter of } \\
2020 \text { (10000 yuan) }\end{array}$ & $\begin{array}{l}\text { Year on year } \\
\text { growth }( \pm \%)\end{array}$ & $\begin{array}{l}\text { Growth } \\
\text { ranking }\end{array}$ \\
\hline 1 & Shinan District & 285.51 & 58.88 & 4.85 & $-4.9 \%$ & 4 \\
\hline 2 & West Coast New Area & 734.43 & 160.82 & 4.57 & $-9.1 \%$ & 10 \\
\hline 3 & Laoshan District & 193.17 & 45.59 & 4.24 & $+0.5 \%$ & 2 \\
\hline 4 & Chengyang District & 212.48 & 74.49 & 2.85 & $-8.1 \%$ & 8 \\
\hline 5 & Jiaozhou City & 236.98 & 90.75 & 2.61 & $-6.6 \%$ & 7 \\
\hline 6 & $\begin{array}{c}\text { Red Island Economic } \\
\text { Zone }\end{array}$ & 27.37 & 10.51 & 2.60 & $+5.0 \%$ & 1 \\
\hline 7 & Licang District & 114.92 & 58.92 & 1.95 & $-4.5 \%$ & 3 \\
\hline 8 & Jimo District & 238.37 & 124.89 & 1.91 & $-9.3 \%$ & 11 \\
\hline 9 & Shibei District & 201.96 & 111.10 & 1.82 & $-6.5 \%$ & 6 \\
\hline 10 & Laixi City & 106.72 & 76.24 & 1.40 & $-5.1 \%$ & 5 \\
\hline 11 & Pingdu City & 130.91 & 137.79 & 0.95 & $-8.7 \%$ & 9 \\
\hline
\end{tabular}




\begin{tabular}{|c|c|c|c|c|c|}
\hline Total & 2504.87 & 949.98 & 2.64 & $-7.1 \%$ & -- \\
\hline
\end{tabular}

According to the data in the table, the GDP of Laoshan District in the first quarter of 2020 is about 19.317 billion yuan, with a year-on-year growth of $0.5 \%$, realizing the growth against the trend. Affected by the epidemic, the economy is basically under stable control, and the year-on-year growth rate ranks first in the city. This data shows that the per capita living expenses of residents in Laoshan District were still increased during the epidemic period.

In order to understand the current situation of the surrounding consumer market, in addition to a more macro survey and analysis, we can also conduct a random sampling questionnaire survey on the people who are consuming in various high consumption places to understand the composition, consumption status, consumption awareness, and satisfaction with the existing consumption environment of the consumer group, so as to help the location and positioning of the lattice shop.

\subsection{Controlling the market environment of micro capital entrepreneurship}

In the past, with the support of national policies, micro entrepreneurs can get part of the profits in the initial operation stage. Most of the micro entrepreneurs in China are from the market. They understand the market, understand marketing and are good at communication, but they are lack of large-scale and standardized management of the enterprise or internal. Due to the imperfection of the internal staff management system and the lack of communication for the operation, the information exchange between the superior and the subordinate and between the superior and the consumer is not smooth, the collection, sorting and analysis of various information and data are not paid attention to, and the lack of a standard system of management means also increases the loss cost, It makes the vitality and advantage of management lose gradually, and leads to the increase of risk. With the arrival of the epidemic, it is even worse for the entrepreneurs with small funds who originally have less risk tolerance. From the micro point of view, for the "lattice shop", every "lattice owner" who deposits private property in the physical store is a "micro investment entrepreneur" in the "lattice shop" market. There is a tripartite relationship of choice, that is, social market environment, "lattice shop" market environment, lattice owners and buyers. Therefore, for any party, it is necessary to initially define the commodity positioning for a fixed market or consumers as far as possible, and then carry out more other commodity business with lattice shop characteristics after adapting to or completely mastering the commodity market competition chain in the region, or having funds in place.

\subsection{Investigation on the market environment of network publicity}

With the coming of the "5G" era of continuous integration of communication and science and technology, the "network + offline" two-way marketing mode is found in the research on the market economy reform in the post epidemic era. When constructing this marketing mode and establishing a fast and effective propaganda mode, it is very important to analyse the environment of the network market. We can design questionnaires suitable for the network and offline distribution methods according to the different target customers. Here, the offline links play a connecting role. They complement each other and have an important impact on the network market environment, the determination and feedback of the current propaganda mode. The Internet social platform commonly used by people around the lattice shop is the most favourable network environment for the lattice shop, and it is also the decision basis for the direction of publicity. Before creating the network market and the way and intensity of publicity, through offline investigation, we can accurately judge the development trend of the two.

\subsection{Customer loyalty control}

Due to the lattice shop itself needs more than one source of goods to supply business model, stable and excellent customer group is the development of lattice shop business must solve the problem. Since the 1980s, some scholars have studied the relationship between the market and consumers, and led to the theoretical research of customer satisfaction, customer loyalty, customer value, which originated from the huge impact of consumers on the market. With the development of science, technology and economy, consumers have more ways to master knowledge, information and skills, and are more interested in exploring new things and practices. Many basic functions of goods can not be the decisive factors for customers to choose lattice shop and goods. Under the trend of double cycle economy at home and abroad, more and more consumers regard the emotional and psychological satisfaction of the store and commodity as one of the selection criteria. In short, the level of market demand continues to improve, and consumer demand presents personalized characteristics. Based on the survey and analysis of the population per capita GDP of Laoshan District in the first quarter of 2020 and the current situation of the surrounding consumer market, we find that after the change of the big market economy environment, the impact of the change on the residents is in proportion to the impact on the surrounding shops. In this market environment, customer 
loyalty is one of the decision-making factors to determine whether lattice shop can continue to operate properly. According to the survey, the driving factors of customer loyalty include satisfaction factors and constraint factors. Product price, product function and quality, store service, time cost, opportunity cost, publicity mode, market reputation, brand image, store and network environment, product commitment, respect psychology and other factors are the driving factors influencing customer satisfaction and loyalty. But in the actual consumer market, different factors have different driving forces for customer loyalty, which factor has a high weight, which factor is the one we should focus on. The restrictive factors refer to the factors that restrict customers' consumption behaviour, which makes customers' consumption behaviour tend to be stable. Restrictive factors are what we usually call transfer barriers. Restrictive factors include: switching costs, social culture and social norms, economic strength and personal factors. Before determining the location of the site, it is necessary to conduct a thorough investigation on the regional market, and obtain the weight of various satisfaction factors and constraint factors of consumers in the region by issuing questionnaires, so as to provide decision-making basis for specific site selection, lattice shop planning and layout, and "lattice owner" investment promotion. At the same time, through the analysis of market research results, on the premise of meeting customer expectations and needs, the project evaluation system beyond customer expectations is developed. The necessity of this system is reflected in the positive impact of customer expectations on the consumer market. Expectation refers to the level that consumers or potential consumers want the products and services provided by businesses to meet their needs. The socalled exceeding customer expectations means that businesses can not only meet the expectations of consumers, but also provide more perfect and more guaranteed products and services, so that they can obtain higher level satisfaction, develop into a stable loyal customer group, and bring word-of-mouth effect to the lattice shop at the same time.

\section{Conclusion}

In the post epidemic era, comprehensive analysis of domestic and international economic forms, relevant national economic planning and development policies, and the construction of entrepreneurial platform will become an emerging service format needed by the market. Through mass entrepreneurship and innovation, relying on the advantages of low-cost lattice shop, combined with efficient management and marketing means, it can promote the rapid capital turnover of small and micro entrepreneurs and obtain more profits. In the process of regional market entry, we should fully consider the market economy scale, demand, regional cooperation, development potential and other factors, combined with our own platform construction ideas and direction, comprehensively carry out market environment research, and select the market positioning and store address in line with the development plan. By integrating new management concepts and all media means, we will continue to increase the influence of products, drive the demand around the market, give full play to the unique advantages of lattice shop, and promote the innovation and development of the industry.

\section{Acknowledgement}

This work was supported by Research on the operation of the "private shelf shop" entrepreneurial platform based on diversified cooperation (S2020104291075).

\section{References}

1. L. Chen, "Analysis on Financial Management of Small and Micro Enterprises Based on Cloud Accounting in Big Data Age," 2020 Management Science Informatization and Economic Innovation Development Conference (MSIEID), Guangzhou, China, 2020, pp. 351-354.

2. C. Chen, L. Chen, M. Xiao and J. Ning, "The Impact Analysis of COVID-19 on China Various Industries Using Crawler Technology and Data Visualization Technology," 2020 IEEE 3rd International Conference of Safe Production and Informatization (IICSPI), Chongqing City, China, 2020, pp. 400-405.

3. Z. Lei and W. Zhaolei, "The Realization Path of Digital Transformation of China's Economic Development Based on SWOT Analysis," 2021 International Conference on Public Management and Intelligent Society (PMIS), Shanghai, China, 2021, pp. 115-118.

4. W. Cheng and H. Lv, "Research on cloud evaluation of rural e-commerce development level in China," 2021 2nd International Conference on ECommerce and Internet Technology (ECIT), Hangzhou, China, 2021, pp. 1-6.

5. X. Liu, Q. Mu and Y. Chen, "Reform and Improvement in China's Rural Financial Sector Based on Internet Technology," 2021 2nd International Conference on E-Commerce and Internet Technology (ECIT), Hangzhou, China, 2021, pp. 310-313. 